\title{
Distributions and seasonal abundances of krill eggs and larvae in the sub-Arctic
} Godthåbsfjord, SW Greenland

\author{
Teglhus, Frederik Wolff; Agersted, Mette Dalgaard; Akther, Hasna; Nielsen, Torkel Gissel
}

Published in:

Marine Ecology Progress Series

Link to article, DOI:

$10.3354 /$ meps 11486

Publication date:

2015

Document Version

Publisher's PDF, also known as Version of record

Link back to DTU Orbit

Citation (APA):

Teglhus, F. W., Agersted, M. D., Akther, H., \& Nielsen, T. G. (2015). Distributions and seasonal abundances of krill eggs and larvae in the sub-Arctic Godthåbsfjord, SW Greenland. Marine Ecology Progress Series, 539, 111 125. https://doi.org/10.3354/meps 11486

\section{General rights}

Copyright and moral rights for the publications made accessible in the public portal are retained by the authors and/or other copyright owners and it is a condition of accessing publications that users recognise and abide by the legal requirements associated with these rights.

- Users may download and print one copy of any publication from the public portal for the purpose of private study or research.

- You may not further distribute the material or use it for any profit-making activity or commercial gain

- You may freely distribute the URL identifying the publication in the public portal 


\title{
Distributions and seasonal abundances of krill eggs and larvae in the sub-Arctic Godthåbsfjord, SW Greenland
}

\author{
Frederik Wolff Teglhus ${ }^{1}$, Mette Dalgaard Agersted ${ }^{1}$, Hasna Akther ${ }^{1}$, \\ Torkel Gissel Nielsen ${ }^{1,2, *}$
}

\author{
${ }^{1}$ National Institute of Aquatic Resources, Section of Oceanography and Climate, Technical University of Denmark, \\ Kavalergården 1D, 2920 Charlottenlund, Denmark \\ ${ }^{2}$ Greenland Climate Research Centre, Greenland Institute of Natural Resources, Kivioq 2, PO Box 570 , 3900 Nuuk, Greenland
}

\begin{abstract}
The larval krill community (Thysanoessa spp.) was investigated along the sub-Arctic Godthåbsfjord, SW Greenland, in June 2010. In addition, the progress of krill development from egg to furcilia was studied from March to August 2010 in a fjord branching off the Godthåbsfjord. Krill spawned from late April until early May, with a second spawning event in early July. Spawning took place in the warmer, innermost part of the fjord, correlated with phytoplankton blooms. Naupliar abundance peaked immediately after spawning, and naupliar stage duration was $3 \mathrm{~d}$. Sequences of the calyptopis and furcilia stages lasted 22 and $63 \mathrm{~d}$, respectively. The growth rate from metanauplius to calyptopis was $0.12 \mathrm{~d}^{-1}$, while the growth rate across all developmental stages was $0.05 \mathrm{~d}^{-1}$. Mortality rates were calculated as $25 \%$ from eggs to nauplii, $48 \%$ from eggs to calyptopes and $83 \%$ from eggs to furcilia. During development, the larvae were dispersed from the shallow, warmer hatching area in the inner part of the fjord to the main fjord by tidal currents and runoff from land. The study showed that developmental stages of krill are a key group in Greenland coastal waters, one which should be considered in future studies of the pelagic food web.
\end{abstract}

KEY WORDS: Thysanoessa spp. · Larval development · Environmental factors

\section{INTRODUCTION}

Krill (Euphausiacea) are a key component in western Greenland marine ecosystems (Einarsson 1945, Agersted et al. 2011). They have the same grazing potential as copepods (Teglhus et al. 2015), thereby forming a major link between primary producers and marine vertebrate predators, including fish, birds and mammals (Mauchline \& Fischer 1969, Astthorsson \& Gislason 1997, Rosing-Asvid et al. 2013). It is crucial to understand the environmental drivers of krill population dynamics to predict how future changes in marine environments will affect plankton communities. Population processes have previously been considered for adult krill (Agersted \& Nielsen 2014). However, basic knowledge about reproduction and particularly development and succession of larval stages of Arctic krill is limited (Timofeyev 1993), providing inadequate background for evaluating how Arctic krill populations will be affected by expected environmental changes.

Krill pass through a number of larval stages before developing into mature adults. After the egg is fertilized and released, embryogenesis produces a freeswimming nauplius that hatches (Mauchline \& Fischer 1969). In successive moults, this larva develops through a metanauplius stage, then 3 calyptopis stages and up to 14 furcilia stages. The calyptopis is 
the first feeding stage, and the larvae may begin to perform diel vertical migrations (Siegel 2000). After the last furcilia stage, the krill becomes a juvenile with most of the adult morphology and finally a sexually mature adult (Mauchline \& Fischer 1969). Knowledge about the biology of krill larvae and the relationships among their spatial and seasonal distributions and experienced physical and biological parameters is essential to understanding krill population dynamics. This has been intensively investigated for the Antarctic species Euphausia superba (Huntley \& Brinton 1991, Flores et al. 2012, Gao et al. 2013), but much less knowledge is available for the North Atlantic and sub-Arctic species (Astthorsson 1990, Astthorsson \& Gislason 1997, Dalpadado et al. 2008, Agersted \& Nielsen 2014).

In the Godthåbsfjord system, the krill population is dominated by Thysanoessa raschii but also includes species of T. inermis, T. longicaudata and Meganyctiphanes norvegica (Agersted \& Nielsen 2014). Sampling for adult krill usually ignores larvae due to the conflicting mesh size requirements and sampling techniques. Furthermore, krill larvae are rarely considered in micro- or mesozooplankton samples, leaving them mostly overlooked. Previous studies on the Godthåbsfjord zooplankton assemblages show linkages between hydrography and assemblage compo- sitions (Calbet et al. 2011, Tang et al. 2011, Arendt et al. 2013), and a recent study by Agersted \& Nielsen (2014) identified zonation of the 4 dominating krill species in relation to hydrography. Nevertheless, despite their obviously key role in this ecosystem, no investigations have been made so far on krill larvae in Greenland coastal waters.

Therefore, our aim in the present study was to investigate the spatial and seasonal successions and vital rates of the developmental stages of krill in relation to hydrography and food in the sub-Arctic Godthåbsfjord.

\section{MATERIALS AND METHODS}

Two complementary studies were carried out; one was a spatial study along the Godthåbsfjord in June, and the other considered the seasonal succession of krill larval stages from March to August in the Kapisigdlit fjord, a side branch to the Godthåbsfjord (Fig. 1).

The Godthåbsfjord is part of the largest fjord system on the western Greenland coast, receiving approximately $7.6 \mathrm{~km}^{3}$ of glacial meltwater annually (Mortensen et al. 2013). Along the $187 \mathrm{~km}$ main fjord branch, there is a temperature and salinity gradient

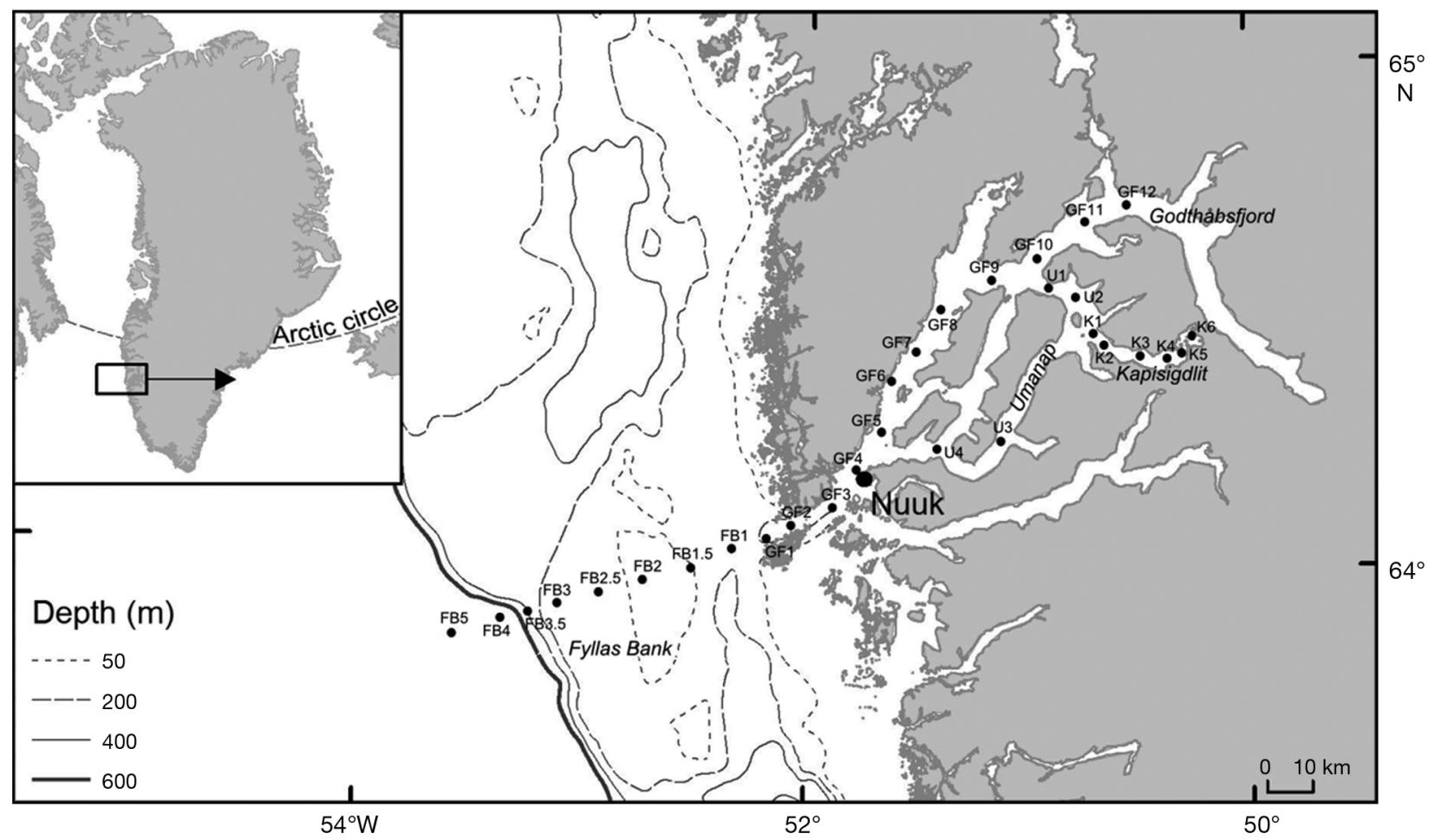

Fig. 1. Godthåbsfjord system showing the location of sampling stations within the study area. FB: Fyllas Bank; GF: Godthåbsfjord; K: Kapisigdlit; U: Umanap 
from warmer water offshore to colder and fresher water at the ice edge. Within the fjord system, 4 different water masses and oceanographic regions can be defined (Mortensen et al. 2011, Tang et al. 2011): (1) the innermost part of the fjord that is most strongly influenced by ice and freshwater runoff from glaciers; (2) the deep regions of the main fjord basin, with strongly stratified water masses; (3) the main sill region at the entrance of the fjord that is influenced by strong tidal mixing; and (4) the offshore area of Fyllas Bank, where the West Greenland Current brings relatively warm and saline water of Atlantic and polar origin (Holland et al. 2008, Myers et al. 2009). Between the mouth of the fjord and the main fjord basin (Stns GF1 to GF6; Figs. 1 \& 2) are 3 sills with depths between 330 and $400 \mathrm{~m}(366 \pm 29 \mathrm{~m}$ mean depth). The main fjord basin (Stns GF8 to GF12) has an average depth of $592 \pm 39 \mathrm{~m}$, whereas Fyllas Bank on the continental shelf rises to $47 \mathrm{~m}$. Stations on the outer part of the continental shelf (e.g. the continental slope) are $>1000 \mathrm{~m}$ (Mortensen et al. 2011). Connected to the main fjord is a side branch, Kapisigdlit fjord, which is influenced by runoff during the summer from the Kapisigdlit River at its head (Riisgaard et al. 2014).

The Godthåbsfjord was sampled during a cruise of the RV 'Dana' (National Institute of Aquatic Resources, Denmark) from June 7 to 22, 2010. Stations were located along a $292 \mathrm{~km}$ transect from the offshore region of Fyllas Bank to the innermost part of Godthåbsfjord (Fig. 1). Along the fjord system, the cruise was split into 4 sections: (1) Umanap fjord branch in the southwestern part (Stns GF4, U3 and U4), (2) an eastern innermost part near the glacier in Godthåbsfjord proper (Stns GF1 to GF12), (3) an offshore region (Stns FB5 to FB1) and (4) an innermost section in Kapisigdlit fjord (Stns GF9, U1, U2 and K1 to K6, Fig. 1). The temporal study was conducted from March 24 to August 5, 2010, in Kapisigdlit fjord (Stns K1 to K6) using the vessel 'Lille Masik' on a total of 14 cruises every 7 to $10 \mathrm{~d}$ along a transect of 6 stations. Stn K1 was located at the mouth of the fjord branch, and Stn K6 was at the inner end (Fig. 1).

\section{Hydrography and chl a}

At each station, vertical profiles of water temperature, salinity and fluorescence were obtained using a CTD profiler (SBE 19plus or 911plus, SeaCat). In Kapisigdlit, water samples for chl a analyses were taken at Stn K4 from 8 depths $(1,10,20,50,75,100$, 150 and $250 \mathrm{~m}$ ) using a 51 Niskin bottle. The seawater samples for chl a concentration were filtered onto GF/F filters in triplicate subsamples of 100 to $500 \mathrm{ml}$. The filters were extracted for 12 to $24 \mathrm{~h}$ in $96 \%$ ethanol (Jespersen \& Christoffersen 1987), and chl a concentrations were measured using a Turner TD-700 fluorometer calibrated against a chl a standard before and after acidification (Yentsch \& Menzel 1963).

\section{Krill sampling}

In the Godthåbsfjord, krill eggs and larvae were collected using a $300 \mu \mathrm{m}$ mesh, $60 \mathrm{~cm}$ diameter Bongo net (eggs, nauplii, metanauplii and calyptopes) and a $500 \mu \mathrm{m}$ mesh Bongo net (furcilia). The nets were towed in oblique hauls from $110 \mathrm{~m}$ at 2.5 knots.

In Kapisigdlit, eggs and larvae were collected with a $300 \mu \mathrm{m}$ mesh, $60 \mathrm{~cm}$ Bongo net until July 5. Subsequently, sampling was carried out with a $600 \mu \mathrm{m}$ mesh Methot Isaacs-Kidd (MIK) ring net $(2 \mathrm{~m}$ diameter, white). Oblique net tows were conducted from the surface to $35-50 \mathrm{~m}$ above the sea floor due to shallow depths and variable bathymetry at the 2 innermost stations, or to a maximum depth of $100 \mathrm{~m}$, at 1.6 knots.

All nets were fitted with a flow meter and a CTD (MicroCat SBE $25 \mathrm{SM}$ ) to record flow of water into the net and haul profiles, respectively. After retrieval, eggs and larvae were preserved in buffered formalin (4\% final concentration). A minimum of 400 individuals from each sample were later sorted by stages (egg, nauplius, metanauplius, calyptopis, furcilia 1 to 9) and counted; carapace length was measured to the nearest $10 \mu \mathrm{m}$. Krill larval stages were identified to genus (Thysanoessa spp.) according to Einarsson (1945). For the seasonal study in Kapisigdlit, additional sampling was conducted with a Multinet (50 $\mu \mathrm{m}$ mesh, Hydrobios mini) hauled vertically at 0.2 to $0.3 \mathrm{~m} \mathrm{~s}^{-1}$. All Multinet samples were preserved in buffered formalin ( $4 \%$ final concentration) and individuals later identified to stage in the Plankton Sorting and Identification Centre, Poland. As eggs were not identified to particular taxa, a size distinction was made. Eggs between 350 and $625 \mu \mathrm{m}$ in diameter were considered as krill eggs following Einarsson (1945).

\section{Gear correction factor}

Oblique hauls with the Bongo and MIK nets were conducted to collect adult krill. The finer-mesh Multinet was used concurrently for younger stages and 


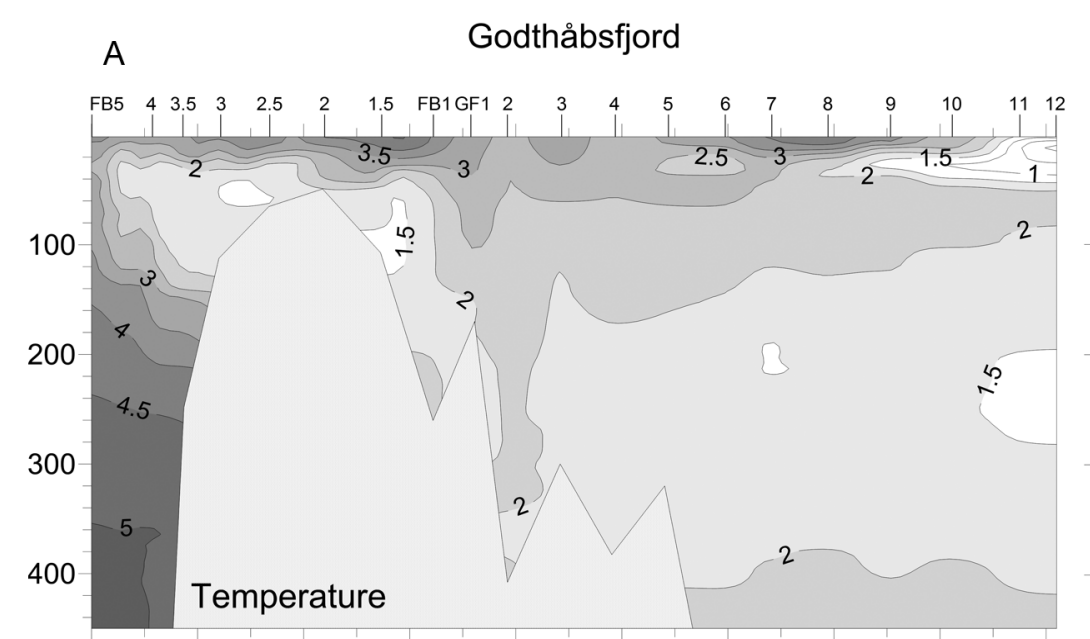

\section{Umanap Kapisigdlit}

\section{B}
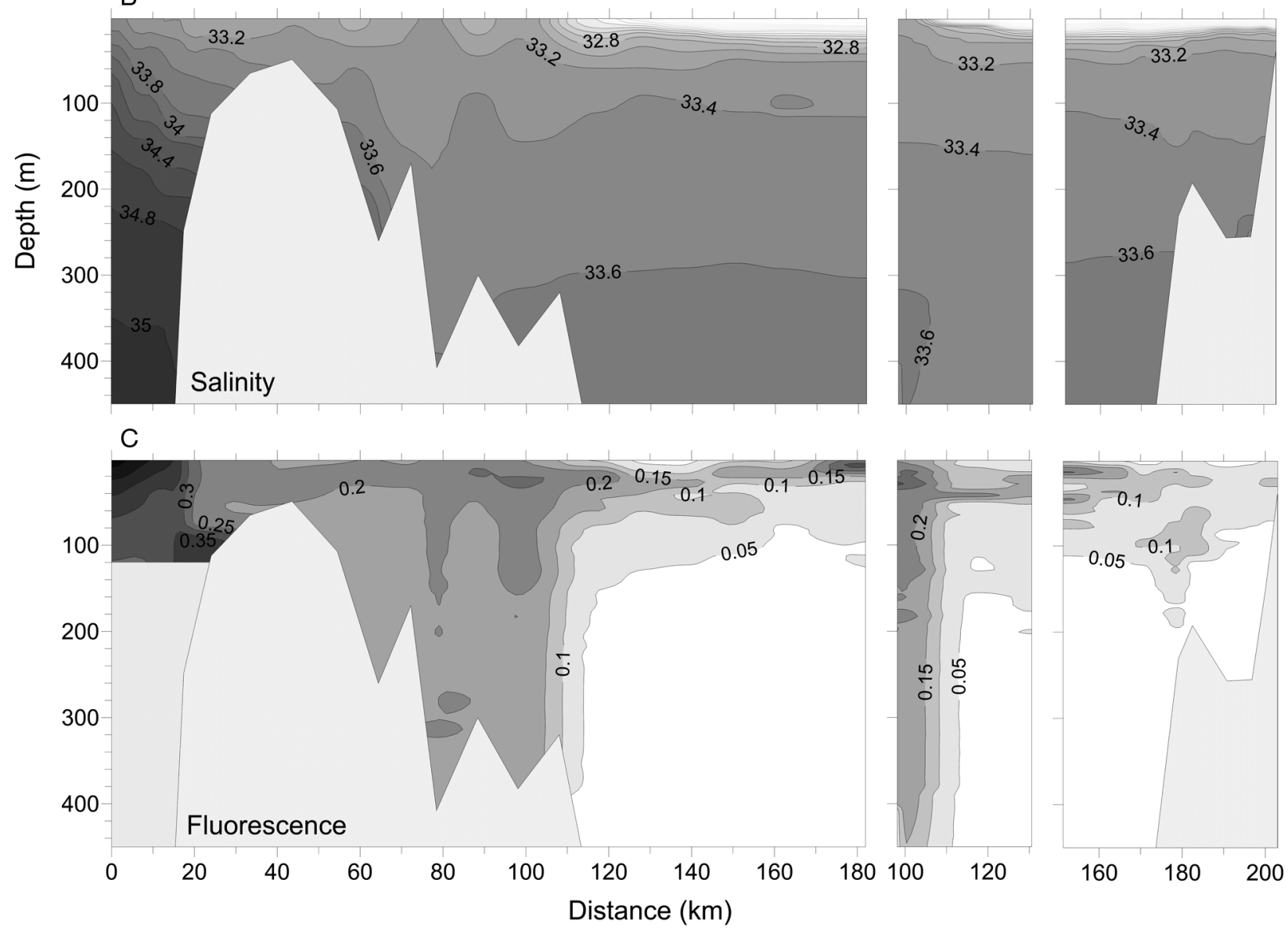

Fig. 2. Hydrography along the Godthåbsfjord, Umanap and Kapisigdlit during June 2010 (see Fig. 1 for stations). (A) Temperature $\left({ }^{\circ} \mathrm{C}\right),(\mathrm{B})$ salinity and (C) fluorescence (arbitrary units). Stations are above and distances between stations are below the graph. Umanap was plotted in conjunction with Godthåbsfjord (Stns GF4, U3 and U4) and Godthåbsfjord and Kapisigdlit (Stns GF9, U1 and U2, K1 to K6)

eggs. During the end of the seasonal study in Kapisigdlit, a coarser-mesh MIK net was applied instead of the Bongo net. A correction factor was calculated to harmonize egg and larval abundance estimates from the different equipment. The correction factor was calculated from a regression between (1) the abundance of a specific stage caught by each net type and (2) the abundance of the stage in consideration esti- 
mated from the gear giving the highest number, assuming this to represent the true abundance (Table 1).

\section{Cumulative development time, growth rates and mortality estimates}

Stage-specific development times for krill larvae from the Kapisigdlit fjord branch were determined using the method of median development time (MDT) as described by Landry (1983). The MDT is defined as the time when $50 \%$ of the population had moulted to a specific stage. This was calculated from least-squares regressions of time versus the proportion of the population which had completed a given moult stage. The initial time was taken as the midpoint between the beginning and end of egg production (Landry 1983).

Development times were converted to rates (the reciprocal of development time) and normalized to a temperature of $5^{\circ} \mathrm{C}$ for comparison with other studies, based on $Q_{10}$ as calculated from data in Pinchuk $\&$ Hopcroft (2006) using the formula:

$$
Q_{10}=\left(\frac{R_{2}}{R_{1}}\right)^{10 /\left(T_{2}-T_{1}\right)}
$$

where $R_{1}$ and $R_{2}=$ development rate $\left(\mathrm{d}^{-1}\right)$ at temperature $T_{1}$ and $T_{2}\left({ }^{\circ} \mathrm{C}\right)$, respectively.

Growth and mortality rates were calculated from the peak average egg and larvae abundances (ind. $\mathrm{m}^{-3}$ ) in the Kapisigdlit fjord.

Daily growth rates $\left(\mathrm{GR}, \mathrm{d}^{-1}\right)$ were calculated by the equation:

$$
\mathrm{GR}=\frac{1}{t_{2}-t_{1}} \times \ln \left(\frac{W_{2}}{W_{1}}\right)
$$

where $t_{2}-t_{1}$ is the estimated time in days between peak abundances of a given stage and the succeed- ing stage, and $W_{1}$ and $W_{2}$ are weights of those stages in $\mu \mathrm{gC}$ at times $t_{1}$ and $t_{2}$, respectively. Length data for each development stage (nauplius, metanauplius, calyptopis and furcilia) were converted from total length (TL) to wet body weight (WW) and then dry body weight (DW) following the regressions from Dalpadado \& Skjoldal (1996):

$$
\begin{aligned}
\log \mathrm{WW} & =3.33 \log \mathrm{TL}-2.58 \\
\mathrm{DW} & =0.34 \mathrm{WW}-1.26
\end{aligned}
$$

Carbon content was then calculated as $48.9 \%$ of total DW (Agersted \& Nielsen 2014).

Mortality rates $(M, \%)$ were calculated by determining the percentages of the individuals surviving from the egg stock to a given stage (Lindley \& Williams 1980):

$$
M=100 \%-\left(\frac{N_{2}}{N_{1}} \times 100\right)
$$

where $N_{1}$ is maximum average egg abundance (ind. $\mathrm{m}^{-3}$ ) and $N_{2}$ is maximum larval abundance for each successive stage (nauplius, metanauplius, calyptopis and furcilia).

\section{RESULTS}

\section{Hydrography and fluorescence, Godthåbsfjord}

During the RV 'Dana' cruise in June, temperature and salinity were high in the offshore region with a stratified water column (Fig. 2). Moving up the fjord, temperature and salinity decreased along the transect. At the mouth of the fjord, strong mixing was apparent (Stns FB1 and GF1 to GF5, Fig. 2). In the main and inner fjord basin, the upper water column was stratified, with freshwater in a thin surface layer

Table 1. Differences in catch efficiency of the 3 net types (Multinet, Bongo net and Methot Isaacs-Kidd [MIK] net) calculated

\begin{tabular}{|c|c|c|c|c|c|c|c|}
\hline Larval stage & $\begin{array}{c}\text { Length } \\
(\text { mean } \pm \mathrm{SD}, \mu \mathrm{m})\end{array}$ & $\begin{array}{c}\text { Multinet } \\
(y)\end{array}$ & $\begin{array}{c}\text { Gear correc } \\
\text { Bongo }(x)\end{array}$ & $\begin{array}{l}\text { ion factor } \\
\text { MIK }(x)\end{array}$ & Equation & $\mathrm{n}$ & $\mathrm{r}^{2}$ \\
\hline Egg & $413 \pm 58$ & 1 & 5 & - & $y=5.4 x+45.5$ & 18 & 0.85 \\
\hline Nauplius & $454 \pm 84$ & 1 & 213 & - & $y=213 x+2$ & 19 & 0.63 \\
\hline Metanauplius & $474 \pm 52$ & 1 & 109 & - & Mean of egg and nauplius & & - \\
\hline Calyptopis & $1262 \pm 540$ & 1 & 20 & - & $y=20 x-11$ & 14 & 0.56 \\
\hline Furcilia & $3624 \pm 889$ & 1 & - & 2 & $y=2.2 x+3.4$ & 6 & 0.95 \\
\hline
\end{tabular}
for each stage. Values give the relative catch efficiency compared to the one with highest catch. Equations for regression between net types and $\mathrm{r}^{2}$ from each regression are also presented. For metanauplii, no data were available from the Multinet. Instead, the mean correction factor from eggs and nauplii was applied, since all of these stages are similarly sized and do not swim. -: this net not used to sample the given stage 
emanating from the inland ice sheet and Kapisigdlit River (see Fig. 2). Because of the runoff, the inner region had lower temperature $\left(\leq 1^{\circ} \mathrm{C}\right)$ and salinity $(\leq 32.8)$ in the upper water column. In Kapisigdlit, surface waters showed higher temperatures (Fig. 2A). Fronts were established on either side of Fyllas Bank, in the central sector of Godthåbsfjord, at the mouth of the Kapisigdlit fjord and in southwestern Umanap.

Subsurface blooms were observed in association with the pycnocline around $20 \mathrm{~m}$ depth in the Godthåbsfjord and Kapisigdlit (Fig. 2C). Fluorescence was highest offshore and close to the glacier and lowest in the central parts of Godthåbsfjord and Kapisigdlit (Fig. 2C).

\section{Seasonal hydrography and fluorescence, Kapisigdlit}

In March and early April, the water column of Kapisigdlit was well mixed in the upper $100 \mathrm{~m}$ and was cold, saline and nutrient rich (Fig. 3). In midApril, warming of the upper $30 \mathrm{~m}$ began in the inner half of the fjord, and a thermocline was established. During the end of April and beginning of May, a subsurface bloom was identified (at Stn K4), and the temperature increased from the mouth of the fjord branch toward the inner fjord. During May, meltwater from land formed a weak halocline at $20 \mathrm{~m}$ depth. This strengthened after the breakup of ice in the Kapisigdlit River around June 20. At Stns K4, K5 and $\mathrm{K} 6$, the upper water column (0 to $25 \mathrm{~m}$ ) became stratified by June, leading to a subsurface bloom in midJune with the highest chl a levels $\left(>10 \mu \mathrm{g} \mathrm{l}^{-1}\right)$ (dark areas, Fig. 3). This stratification was most likely caused by the release of freshwater from the river. The inner part of the fjord (Stn K6) experiences higher surface temperatures earlier than stations farther out (Stns K4 and K5). Chl a levels seemed generally stable in March to April and again in June to August.

\section{Abundance, spatial distribution and composition of krill larvae in Godthåbsfjord}

Total abundance (mean \pm SD) of eggs, nauplii, metanauplii, calyptopes and furcilia 1 to 4 averaged $470 \pm 700$ ind. $\mathrm{m}^{-3}$, with the highest abundance of 3224 ind. $\mathrm{m}^{-3}$ in the central part of the fjord (Stn GF8) (Table 2, Fig. 4). On the continental slope and shelf (Stns FB2 to FB5) and in the outer sill region (Stns GF1 and GF2), abundance was lower (Table 2,
Fig. 4). Low abundances were also found in Kapisigdlit (Stns K1 to K5) and Umanap (Stn U4) (Table 2).

Egg abundances were highest at Stns GF5 to GF8 and peaked at Stn GF8 with a maximum abundance of 244 eggs $\mathrm{m}^{-3}$. In Kapisigdlit and Umanap, egg abundance was highest at the entrance, with 29 and 33 eggs $\mathrm{m}^{-3}$ at Stns K1 and U2, respectively.

Nauplii and metanauplii were dispersed throughout the fjord (Fig. 4). However, the average relative contribution $(\% \pm \mathrm{SD})$ of nauplii was lower than that of metanauplii (21 \pm 14 and $33 \pm 16 \%$, respectively). Highest abundances of nauplii and metanauplii were found at Stn GF8, with 1332 nauplii $\mathrm{m}^{-3}$ and 1084 metanauplii $\mathrm{m}^{-3}$ (Table 2).

The relative contribution of calyptopes to the total larvae abundance was generally high throughout the fjord (average of $45 \pm 24 \%$ ), with the highest number of 583 calyptopis larvae $\mathrm{m}^{-3}$ at Stn GF8. In Umanap and Kapisigdlit, abundance of calyptopes peaked in the central regions, with 206 and 210 ind. $\mathrm{m}^{-3}$ (at Stns $\mathrm{U} 2$ and $\mathrm{U} 3$, respectively) and 248 and 258 ind. $\mathrm{m}^{-3}$ (at Stns K3 and K4, respectively) (Table 2).

Abundances of furcilia were generally low throughout the fjord. Furcilia stages were mostly found in the offshore region (Stns FB5 and FB3). But higher abundances of furcilia were also found at the mouth of the Kapisigdlit (Stn K2) and Umanap (Stn U2), with 7 and 2 furcilia $\mathrm{m}^{-3}$, respectively (Table 2). Furcilia 1 and 2 (FI and FII) stages dominated. Later stages (FIII and FIV) were only observed at Stns FB3.5 and FB5, $\mathrm{K} 1$ to K2 and U1 to U2. Furcilia abundance was lowest over the outer sill and in the main fjord basin (Stns GF2 to GF8), with 0.02 to 1.3 ind. $\mathrm{m}^{-3}$, with the highest abundance at Stn GF8.

\section{Seasonal distribution and succession of eggs and larvae in Kapisigdlit}

The seasonal succession of krill egg and larval stages was observed from March to August 2010. Krill initiated spawning between April 3 and 22 (Fig. 5A), when the average temperature in the upper $30 \mathrm{~m}$ was between 0.8 and $2.1^{\circ} \mathrm{C}$. Egg abundance peaked in late April (380 eggs $\mathrm{m}^{-3}$ on April 30) to early May (1130 eggs $\mathrm{m}^{-3}$ on May 10 ) in the inner creek (Fig. 5A). Egg abundance was lower in the outer region of the fjord than close to the tributary creek (Fig. 5A). Egg abundance was low during late May and June, but concentration peaked again with 426 eggs $\mathrm{m}^{-3}$ estimated at the beginning of July (Stn K5, Fig. 5A). The majority of eggs were restricted 



Fig. 3. Temporal variation of temperature and salinity of stations along the Kapisigdlit fjord between March 24 and August 5 , 2010. Seasonal development in $\mathrm{chl} \mathrm{a}\left(\mathrm{gg} \mathrm{l}^{-1}\right)$ only available for Stn K4 (right panel). Note different scales on $y$-axis 
Table 2. Abundance data of adult krill (Thysanoessa raschii, T. inermis, T. longicaudata and Meganyctiphanes norvegica, all combined) and different life stages (egg, nauplius [N], metanauplius [MN], calyptopis [C] and furcilia 1 to 4 [FI to FIV]) of Thysanoessa spp. along the transect in the Godthåbsfjord. -: no data

\begin{tabular}{|c|c|c|c|c|c|c|c|c|c|c|c|c|c|}
\hline \multirow[t]{2}{*}{ Stn } & \multirow{2}{*}{$\begin{array}{c}\text { Date } \\
(2010)\end{array}$} & \multirow[t]{2}{*}{$\begin{array}{l}\text { Depth } \\
\text { (m) }\end{array}$} & \multirow[t]{2}{*}{$\begin{array}{l}\text { Adults }{ }^{\mathrm{a}} \\
\text { (ind. } \mathrm{m}^{-3} \text { ) }\end{array}$} & \multirow{2}{*}{ Total } & \multicolumn{7}{|c|}{$\begin{array}{l}\text { Euphausiid larvae } \\
- \text { Abundance (ind. } \mathrm{m}^{-3} \text { ) }\end{array}$} & \multirow[b]{2}{*}{ FIV } & \multirow[b]{2}{*}{ Furcilia total } \\
\hline & & & & & Egg & $\mathrm{N}$ & $\mathrm{MN}$ & $\mathrm{C}$ & FI & FII & FIII & & \\
\hline FB5 & Jun 7 & $0-110$ & 0.03 & 229 & 6 & - & - & 202 & 10 & 10 & 0.5 & - & 21 \\
\hline FB4 & Jun 7 & $0-110$ & 0.01 & 37 & 3 & 18 & 2 & 13 & 1 & 1 & - & - & 2 \\
\hline FB3.5 & Jun 9 & $0-125$ & $0.002 \pm 0.001^{\mathrm{b}}$ & 276 & 5 & 90 & 111 & 64 & 4 & 1 & 0.5 & 0.5 & 6 \\
\hline FB3 & Jun 10 & $0-80$ & 0.002 & 15 & - & - & - & - & 8 & 7 & - & - & 15 \\
\hline FB2.5 & Jun 10 & $0-60$ & 0.004 & 188 & 0 & 49 & 86 & 53 & 0.2 & 0.1 & - & - & 0.3 \\
\hline FB2 & Jun 10 & $0-40$ & $0.0005 \pm 0.0004^{\mathrm{b}}$ & 138 & 1 & 34 & 17 & 83 & 3 & 1 & - & - & 4 \\
\hline FB1.5 & Jun 10 & $0-95$ & - & 889 & 10 & 142 & 145 & 591 & 1 & 0.5 & - & - & 1.5 \\
\hline FB1 & Jun 10 & $0-110$ & 0.04 & 366 & 3 & 158 & 168 & 34 & 2 & 2 & - & - & 4 \\
\hline GF1 & Jun 12 & $0-110$ & 0.01 & 139 & 1 & 7 & 22 & 106 & 1 & 1 & - & - & 2 \\
\hline GF2 & Jun 13 & $0-110$ & 0.27 & 238 & 0 & 28 & 91 & 118 & 0.2 & 0.1 & - & - & 0.3 \\
\hline GF4 & Jun 14 & $0-110$ & 0.001 & 333 & 8 & 63 & 158 & 104 & 0.1 & 0.1 & - & - & 0.2 \\
\hline GF5 & Jun 15 & $0-110$ & 0.32 & 1140 & 46 & 411 & 444 & 239 & 0.1 & 0.04 & - & - & 0.14 \\
\hline GF6 & Jun 15 & $0-110$ & 0.09 & 1340 & 19 & 359 & 676 & 286 & 0.01 & 0.01 & - & - & 0.02 \\
\hline GF8 & Jun 15 & $0-110$ & 1.02 & 3224 & 224 & 1332 & 1084 & 583 & 1 & 0.3 & - & - & 1.3 \\
\hline GF10 & Jun 16 & $0-110$ & $2.25 \pm 0.8^{\mathrm{b}}$ & 61 & 9 & 3 & 19 & 31 & - & - & - & - & 0 \\
\hline K1 & Jun 17 & $0-110$ & 2.42 & 85 & 29 & 10 & 24 & 20 & 2 & 1 & 1 & 0.1 & 3.1 \\
\hline K2 & Jun 17 & $0-110$ & 1.13 & 7 & - & - & - & - & 4 & 3 & 0.3 & 0.2 & 7.5 \\
\hline K3 & Jun 17 & $0-110$ & - & 480 & 2 & 55 & 174 & 248 & 0.3 & 0.1 & 0.03 & - & 0.43 \\
\hline $\mathrm{K} 4$ & Jun 17 & $0-110$ & $0.7 \pm 0.2^{\mathrm{b}}$ & 299 & - & - & 36 & 258 & 3 & 2 & - & - & 5 \\
\hline K5 & Jun 17 & $0-110$ & 0.02 & 30 & - & - & 4 & 24 & 0.4 & 1 & 0.1 & - & 1.5 \\
\hline U2 & Jun 16 & $0-110$ & 1.20 & 588 & 33 & 30 & 318 & 206 & 1 & 1 & 0.1 & - & 2.1 \\
\hline U3 & Jun 22 & $0-110$ & 1.49 & 615 & 1 & 52 & 351 & 210 & 1 & 0.2 & 0.2 & 0.1 & 2.5 \\
\hline U4 & Jun 22 & $0-110$ & 0.03 & 93 & 1 & 11 & 29 & 52 & 0.2 & 0.1 & - & - & 0.3 \\
\hline
\end{tabular}

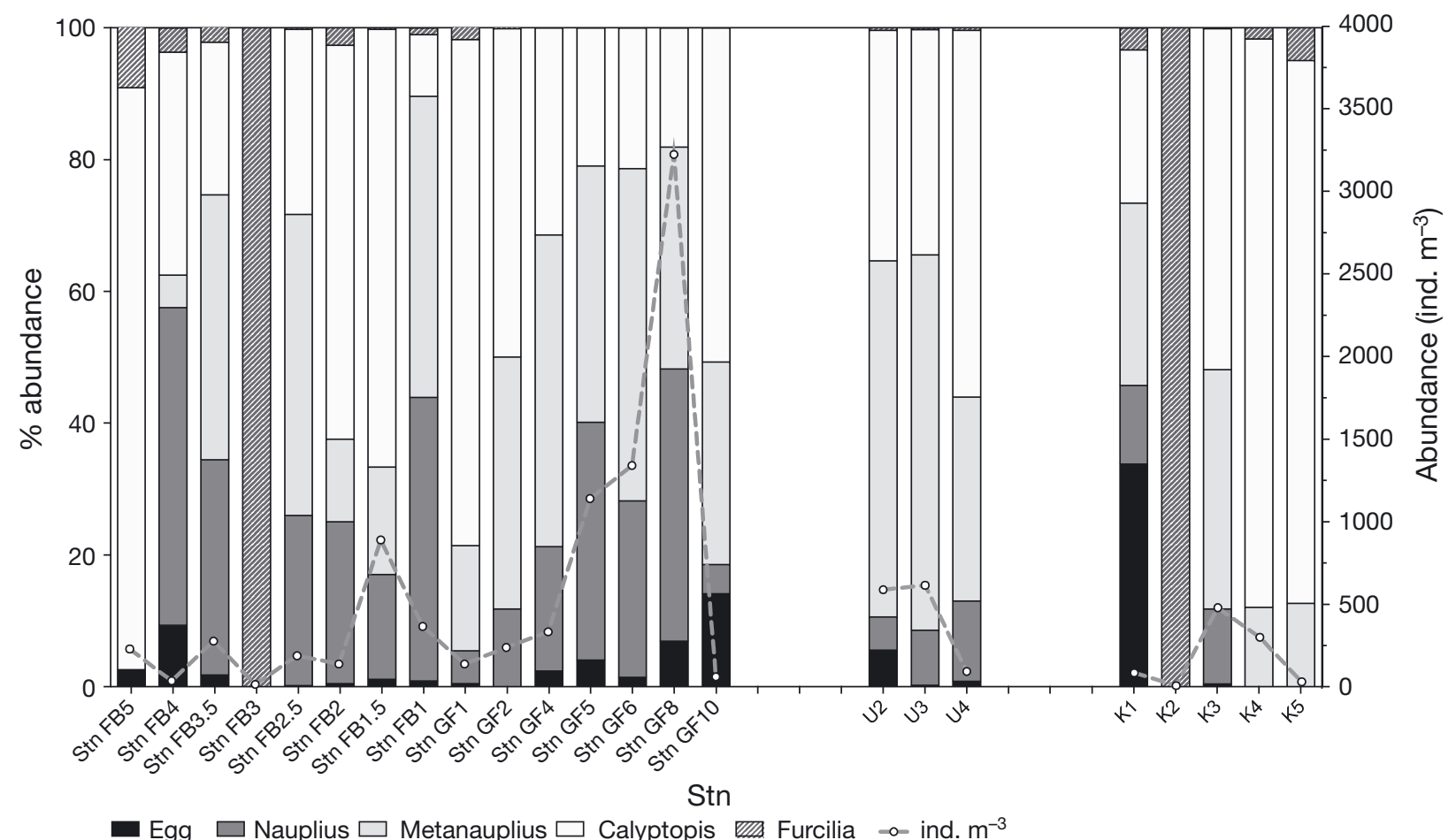

Fig. 4. Total larval abundances and relative contribution of the different life stages of krill throughout the Godthåbsfjord system, June 2010 

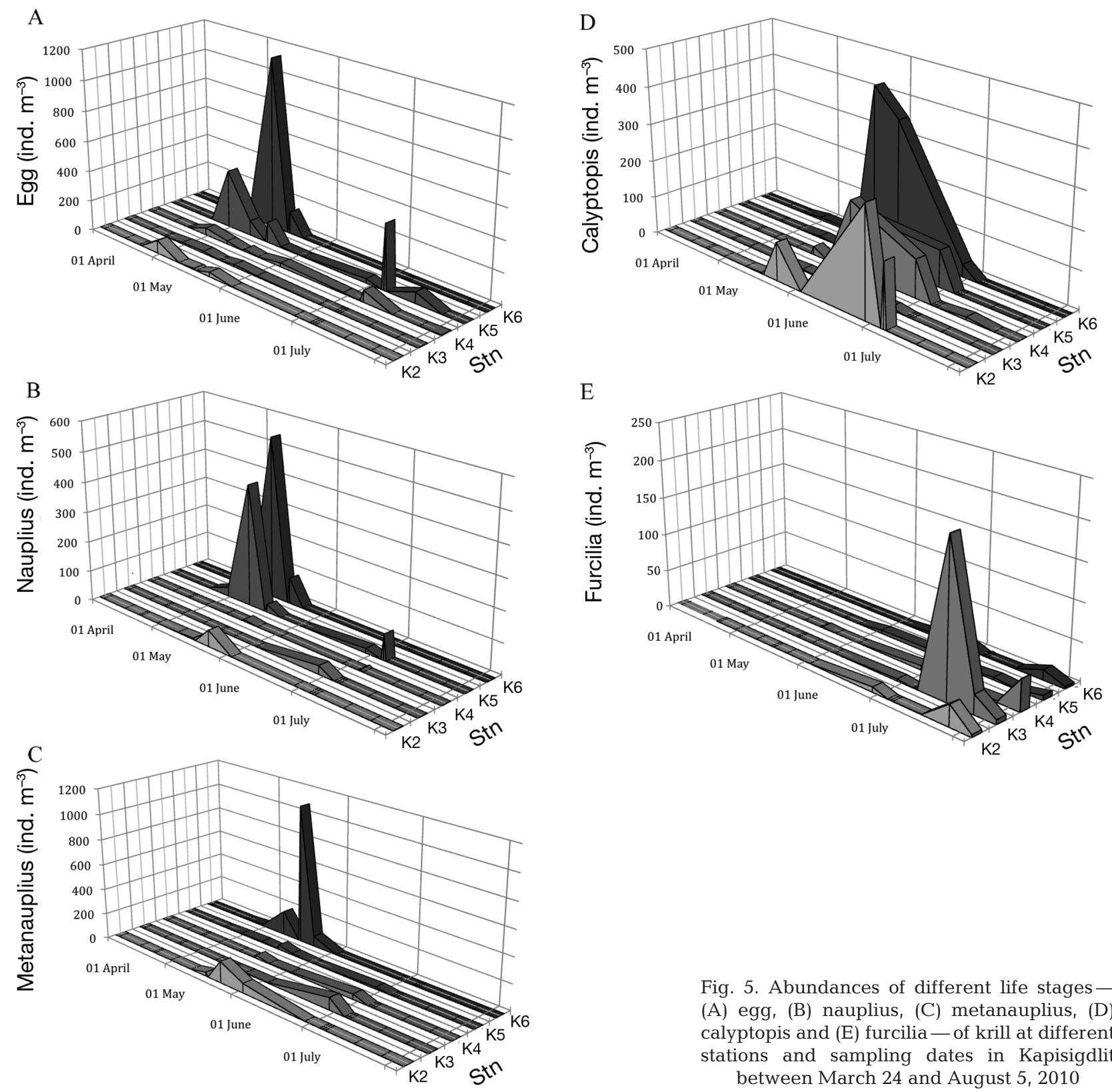

Fig. 5. Abundances of different life stages (A) egg, (B) nauplius, (C) metanauplius, (D) calyptopis and (E) furcilia - of krill at different stations and sampling dates in Kapisigdlit between March 24 and August 5, 2010

to the upper $50 \mathrm{~m}$ during the main spawning period (Fig. 6A).

Nauplii first appeared in samples on April 22, approximately $19 \mathrm{~d}$ after first observation of eggs. The number of nauplii was lower at the mouth of the fjord than in the inner part, where it peaked around May 10 (540 ind. $\mathrm{m}^{-3}$, Stn K6) or May 17 (407 ind. $\mathrm{m}^{-3}$, Stn K5) (Fig. 5B). As for eggs, nauplii were primarily caught in the upper water column during their main abundance peak (Fig. 6B).

Metanauplii were first recorded on April 30 (Stns K5 and K6), and their abundance peaked on May 18 (1085 ind. $\mathrm{m}^{-3}$ ) at Stn K6 (Fig. 5C). Calyptopis stages

were first found on April 30. Their abundance peaked on May 24 (423 ind. $\mathrm{m}^{-3}$ ) in the inner region of the fjord branch (Stn K6), on June 3 (188 ind. $\mathrm{m}^{-3}$ ) at Stn K4 and on June 29 (294 ind. $\mathrm{m}^{-3}$ ) at Stn K2 (Fig. 5D).

Calyptopes were concentrated in the upper $50 \mathrm{~m}$ of the water column (93\%) (Fig. 6C). Calyptopes appeared in succession after the egg, nauplius and metanauplius peaks, but they were generally more evenly distributed throughout the fjord branch (Fig. 5D). Furcilia were present from early June and peaked in abundance on July 18 (206 ind. $\mathrm{m}^{-3}$ ) at Stn K3, on July 28 (28 ind. $\mathrm{m}^{-3}$ ) at Stn $\mathrm{K} 2$ and on 


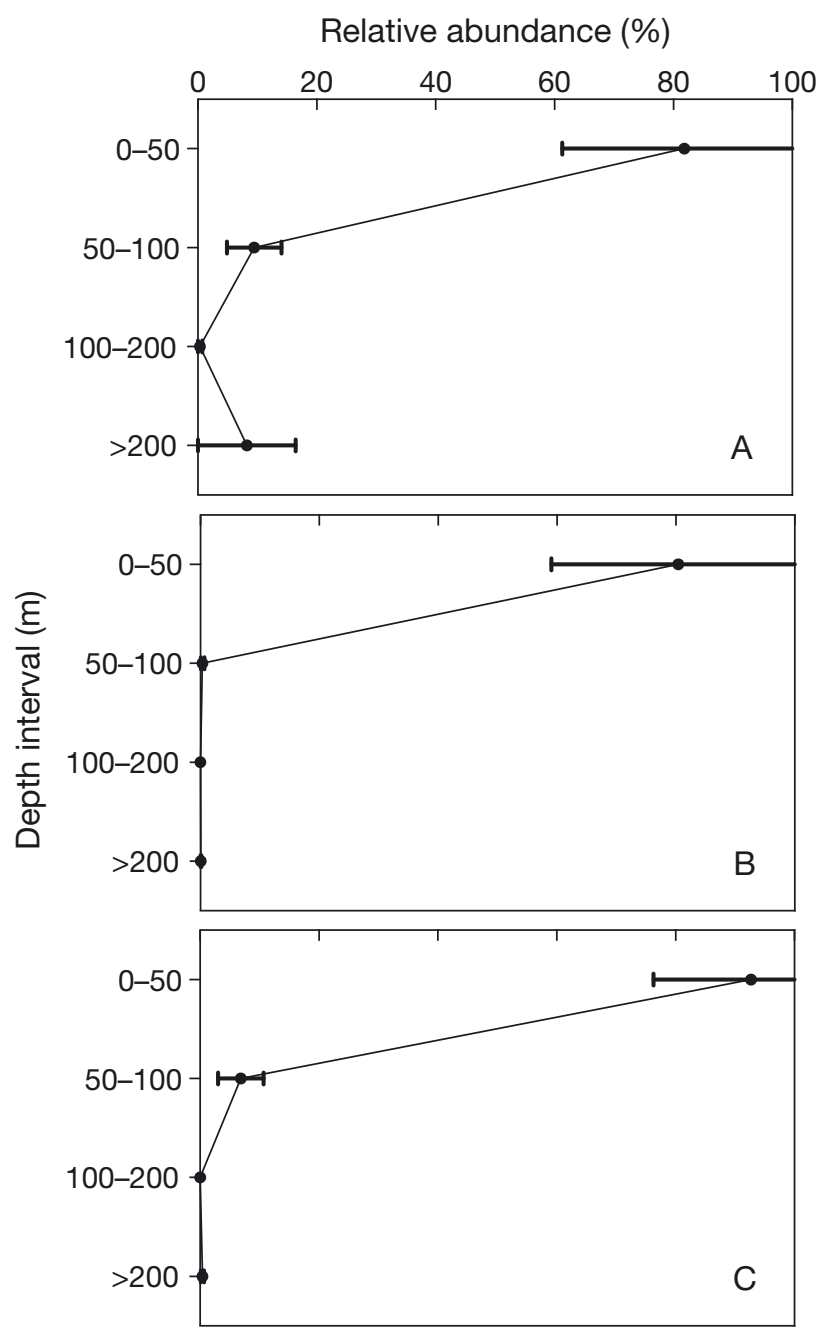

Fig. 6. Depth distributions of (A) eggs, (B) nauplii and (C) calyptopes caught with the Multinet (\% of total abundance \pm $\mathrm{SE})$ during periods with maximum abundance $(\mathrm{n}=4 \mathrm{~d}$ ) (see Fig. 5). Distribution is presented at 4 depth intervals: 0 to 50 , 50 to 100,100 to 200 and $>200 \mathrm{~m}$

August 5 (42 ind. $\mathrm{m}^{-3}$ ) at Stn K4 (Fig. 5E). This was approximately 3 mo after the very first krill eggs were observed and 60 to $65 \mathrm{~d}$ after the peak abundance of krill eggs.

The average abundance (ind. $\mathrm{m}^{-3} \pm \mathrm{SE}$ ) sequence of larval stages followed the progression of ontogenetic development at all stations in Kapisigdlit (Fig. 7). Immediately after spawning (Fig. 7A), there was an increase in nauplii and metanauplii (190 and 287 ind. $\mathrm{m}^{-3}$, respectively) (Fig. $7 \mathrm{~B}, \mathrm{C}$ ), followed by

Fig. 7. Seasonal abundances of eggs and larvae of krill, mean of all stations \pm SE) in Kapisigdlit from March 24 to August 5, 2010. (A) Eggs, (B) nauplii, (C) metanauplii, (D) calyptopes and (E) furcilia. Note different scales on $y$-axes
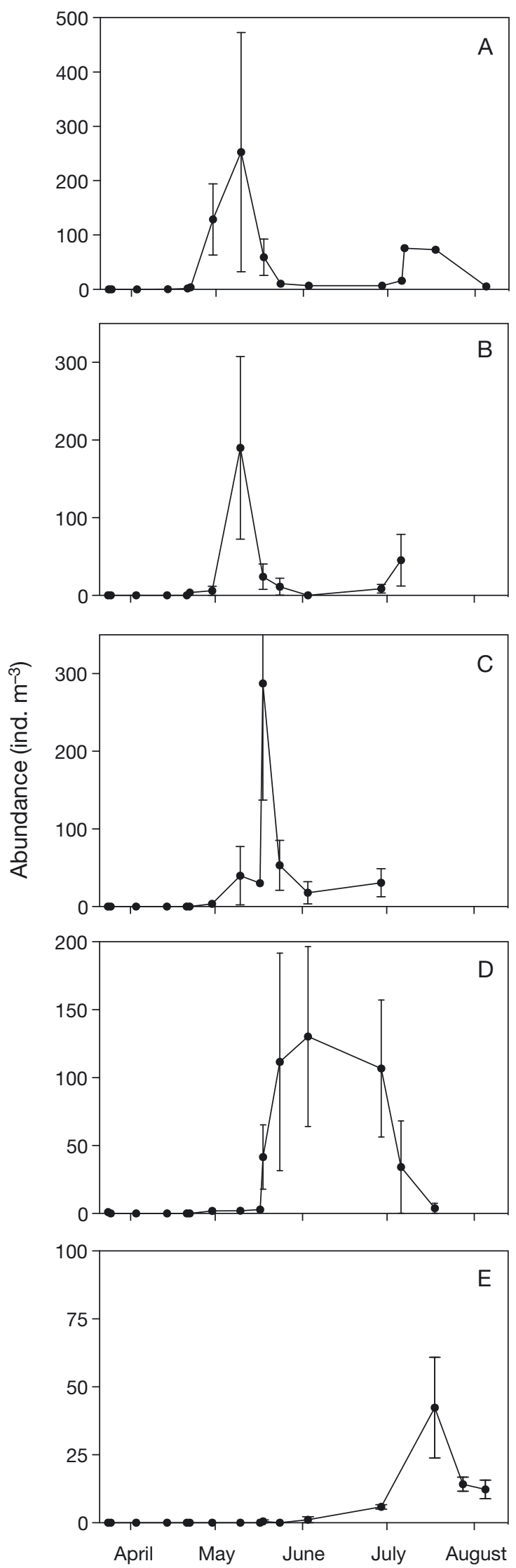
Table 3. Cumulative development times (d) for different life stages of krill larvae, standardized to $5^{\circ} \mathrm{C}$ with a $Q_{10}$ of 2.04 calculated from data by Pinchuk \& Hopcroft (2006) (see 'Materials and methods'). The original experimental temperatures are presented in parentheses for each study

\begin{tabular}{|c|c|c|c|c|c|c|c|c|}
\hline \multirow{2}{*}{ Stage } & \multicolumn{3}{|c|}{ _ Thysanoessa spp. } & \multicolumn{3}{|c|}{ Thysanoessa inermis } & \multicolumn{2}{|c|}{ Euphausia superba } \\
\hline & $\begin{array}{l}\text { This study } \\
\left(5-8^{\circ} \mathrm{C}\right)\end{array}$ & $\begin{array}{l}\text { Buchholz } \\
\text { et al. } \\
(2012) \\
\left(4^{\circ} \mathrm{C}\right)\end{array}$ & $\begin{array}{c}\text { Pogodin } \\
(1980) \\
\left(7-8^{\circ} \mathrm{C}\right)\end{array}$ & $\begin{array}{l}\text { Lindley } \\
\text { \& Williams } \\
(1980) \\
\left(6-10^{\circ} \mathrm{C}\right)\end{array}$ & $\begin{array}{c}\text { Pinchuk } \\
\text { \& Hopcroft } \\
(2006) \\
\left(5^{\circ} \mathrm{C}\right)\end{array}$ & $\begin{array}{c}\text { Pinchuk } \\
\& \text { Hopcroft } \\
(2006) \\
\left(12^{\circ} \mathrm{C}\right)\end{array}$ & $\begin{array}{l}\text { Ikeda } \\
(1984) \\
\left(0^{\circ} \mathrm{C}\right)\end{array}$ & $\begin{array}{c}\text { McWhinnie } \\
\text { \& Denys } \\
(1978) \\
\left(1.5^{\circ} \mathrm{C}\right)\end{array}$ \\
\hline Egg & 0 & 0 & 0 & 0 & 0 & 0 & 0 & 0 \\
\hline Nauplius & 3 & 4.5 & & 11 & 2 & 6 & $6-9$ & 3 \\
\hline Metanauplius & 16 & & & & 6 & 14 & 14 & $8-14$ \\
\hline Calyptopis & 22 & & $15-16$ & $30-41$ & 10 & 29 & $21-37$ & \\
\hline Furcilia & 63 & & & & 33 & 44 & $44-89$ & \\
\hline
\end{tabular}

Table 4. Growth and biometrical parameters of krill larvae at different development periods. Length (mean $\pm \mathrm{SD}$ ), carbon weight and daily growth rates. Daily rations in \% body carbon $\mathrm{d}^{-1}$. -: no data

\begin{tabular}{|lcccccc|}
\hline $\begin{array}{l}\text { Date } \\
(2010)\end{array}$ & Stage & $\mathrm{n}$ & $\begin{array}{c}\text { Length } \\
(\mathrm{mm})\end{array}$ & $\begin{array}{c}\text { Weight } \\
(\mu \mathrm{g} \mathrm{C})\end{array}$ & $\begin{array}{c}\text { Growth } \\
\text { rate }\left(\mathrm{d}^{-1}\right)\end{array}$ & $\begin{array}{c}\text { Daily ration } \\
\left(\% \mathrm{~d}^{-1}\right)\end{array}$ \\
\hline May 10 & Nauplius & 127 & $0.46 \pm 0.03$ & 3.5 & - & - \\
May 18 & Metanauplius & 150 & $0.50 \pm 0.01$ & 4.0 & 0.017 & 5.2 \\
Jun 3 & Calyptopis & 221 & $1.68 \pm 0.5$ & 25.7 & 0.117 & 37.2 \\
Jul 18 & Furcilia & 269 & $4.90 \pm 1.2$ & 123.0 & 0.035 & 10.6 \\
Full period & - & - & - & - & 0.052 & 15.9 \\
\hline
\end{tabular}

However, knowledge about the ecology of nauplii is limited (Kiørboe \& Sabatini 1995, Turner 2004, Jung-Madsen et al. 2013), particularly for the ecology of Arctic krill nauplii (Drobysheva 1987, Dalpadado \& Skjoldal 1991). Here, we provide a first description of the spatial and seasonal distribution of krill larvae in SW Greenland. increases in calyptopis and furcilia abundance later in the season (130 and 42 ind. $\mathrm{m}^{-3}$, respectively) (Fig. 7D,E). Eggs developed into nauplii within $3 \mathrm{~d}$, and those developed into metanauplii within $16 \mathrm{~d}$ from spawning. After $22 \mathrm{~d}$, the larvae had developed to the calyptopis stage and after $63 \mathrm{~d}$ to the furcilia stage (see 'Materials and methods', Table 3).

Larval growth rates were highest from metanauplius to calyptopis $\left(0.12 \mathrm{~d}^{-1}\right.$, or $37 \%$ body carbon $\left.\mathrm{d}^{-1}\right)$, while the overall daily growth rate for the whole period across all developmental stages was $0.052 \mathrm{~d}^{-1}$, or $16 \%$ body carbon $\mathrm{d}^{-1}$ (Table 4 ). Mortality rates calculated from the maximum average egg and larval abundances (ind. $\mathrm{m}^{-3}$ ) were calculated as $25 \%$ for egg to nauplius, $48 \%$ by the calyptopis stage and $83 \%$ from egg to furcilia.

\section{DISCUSSION}

Our data show that development stages of krill are a key plankton community component in Greenland coastal waters. In general, crustacean nauplii are the most numerous metazoan group in the seas (Bjørnberg 1984) and the most important first prey for the majority of fish larvae (Pedersen \& Fossheim 2008).

\section{Spawning, maturity and seasonal distribution of larvae}

A clear succession from egg to calyptopis was documented in Kapisigdlit fjord. Krill eggs increased in abundance during late April and early May, following initiation of spawning. Spawning by species of Thysanoessa has previously been observed in April and May in Iceland (Astthorsson 1990, Gislason \& Astthorsson 1995), the Barents Sea (Dalpadado \& Skjoldal 1991), the North Sea (Lindley \& Williams 1980) and the St. Lawrence estuary (Plourde et al. 2010). During April to May, surface water temperature increased from $1^{\circ} \mathrm{C}$ to approximately $5^{\circ} \mathrm{C}$ in the inner part of the fjord, and a phytoplankton bloom was apparent (Stn K4).

In the Godthåbsfjord system, the population of krill consists of Thysanoessa raschii, T. inermis, T. longicaudata and Meganyctiphanes norvegica (Agersted \& Nielsen 2014). However, the absence of smaller individuals and non-fertilized females of $M$. norvegica suggests that this species does not reproduce in the fjord but is advected from outside the fjord (Agersted \& Nielsen 2014). Astthorsson (1990) and FalkPetersen \& Hopkins (1981) suggest a similar influx of M. norvegica to the Isafjord-deep and Balsfjorden, 
respectively. The spawning in Kapisigdlit is therefore assumed to be that of Thysanoessa spp. Several authors have suggested that spawning of Thysanoessa spp. coincides with the onset of the phytoplankton spring bloom (Einarsson 1945, Berkes 1976, Lindley \& Williams 1980, Falk-Petersen \& Hopkins 1981, Astthorsson 1990, Gislason \& Astthorsson 1995, Dalpadado 2006, Plourde et al. 2010), which is further supported by the present results.

During the study period, there was a second peak in egg abundance at the beginning of July, indicating a second spawning event, as described by MacDonald (1928) for T. raschii in the Firth of Clyde. The second spawning period observed in the present study correlates with the subsurface phytoplankton bloom, with a


possible that the second spawning event observed here can be attributed to T. raschii. Studies have documented later spawning in $T$. raschii compared to $T$. inermis in the Gulf of St. Lawrence and the Balsfjorden (Berkes 1976, Falk-Petersen \& Hopkins 1981, Plourde et al. 2010), and Drobysheva (1987) showed a prolonged spawning season for T. raschii in the Barents Sea, which could lead to less interspecific competition. Agersted \& Nielsen (2014) found that females of T. raschii were fertilized, that is they carried spermatophores, during the study period in June 2010, whereas $T$. inermis females with spermatophores were much less abundant. The 2 time-separated peaks in egg abundance could therefore be related to spawning by $T$. inermis and $T$. raschii, respectively. However, in the future, species molecular identification of eggs will be necessary to support this hypothesis.

Egg and nauplius abundances were highest in the shallow, warmer inner fjord (Stns K5 and K6), despite the outward-moving flow of the subsurface layer (Mortensen et al. 2011). Similarly, Einarsson (1945) and Astthorsson (1990) reported spawning of T. raschii in the inner parts of Seydisfjord, Reydarfjord and Isafjord-deep on Iceland. The inner parts of fjords have weaker mixing and greater inputs of nutrient-rich runoff, resulting in stratification and favourable growth conditions for phytoplankton (Astthorsson 1990, Mortensen et al. 2011). Chlorophyll data were only available from Stn K4. However, Kjellerup et al. (unpubl.) found the highest chl a concentrations during April 2010 at the inner station

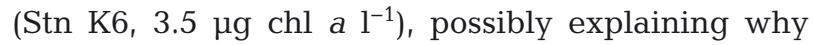
spawning primarily took place there.

Spawning occurred in the surface layers where food concentrations were highest. Multinet samples showed eggs to be concentrated in the upper $50 \mathrm{~m}$, as previously described for Thysanoessa spp. in Scottish waters by Mauchline \& Fisher (1969). Development times showed cumulative development from egg to nauplius within $3 \mathrm{~d}$ and to metanauplius within $16 \mathrm{~d}$. Temperature is known to have a positive effect, with a higher temperature resulting in faster development (Ikeda 1984, Ross et al. 1988, Pinchuk \& Hopcroft 2006). The present results are comparable to earlier findings on development times for Thysanoessa spp.(Buchholz et al. 2012) and Euphausia superba (McWhinnie \& Denys 1978, Ikeda 1984) and are supported by findings suggesting development time of T. raschii egg to nauplius within $3 \mathrm{~d}$ at $3^{\circ} \mathrm{C}$ (M. D. Agersted unpubl. data). It should be emphasized, however, that the development times presented in Table 3 originate from different experimental procedures and conditions, e.g. in situ data are affected by fluctuations in temperature, compared to controlled laboratory experiments. Furthermore, a recent study by Bi et al. (2011) suggests that stage-specific development times for stage-structured marine organisms can be biased when the methodologies used only consider information on survivors.

Calyptopis larvae were dispersed more evenly along Kapisigdlit fjord than the younger stages (Fig. 5D). Kapisigdlit has a classical estuarine circulation, driven by freshwater input from land. As the main sources of freshwater are located in the inner parts of the fjord, the mean water advection out of the fjord is in the surface layer, while an inflow of water is present in the layers below (Swalethorp et al. 2014). The early development from egg to first calyptopis (CI) depends exclusively on internal energy reserves, after which feeding becomes critical. The CI stage only can survive for a maximum of 1 to $2 \mathrm{wk}$ without food (Ikeda 1984, Siegel 2000, Gao et al. 2013). As a result, calyptopis stages are expected to ascend toward the surface, where food concentration is higher (Gao et al. 2013). Tidal advection and currents, therefore, most likely drive dispersal of calyptopis larvae from the inner region out into the fjord. Development time from egg to calyptopis was $22 \mathrm{~d}$, which subsequently meant that calyptopes started to ascend toward the surface in early and mid-June (Table 3). This supports the theory of advectiondriven dispersal, since during the season in which calyptopes increased, there was strong advection out of the fjord from a sudden freshwater outflow caused by the breakup of the ice in the Kapisigdlit River. That would have carried these later-stage larvae out into the fjord.

Modelling of krill movement in the Scotia Sea has suggested that krill can be dispersed by advection (Murphy et al. 2004), and a recent study on cod lar- 
vae (Gadus morhua) in Kapisigdlit illustrates similar patterns in their distribution (Swalethorp et al. 2014). Any changes in tidal advection and timing or magnitude of freshwater input must therefore be considered likely to influence larval distributions and transport through the fjord system. Furthermore, since the duration of the non-feeding stages from hatching to moulting into $\mathrm{CI}$ is temperature dependent (Pinchuk \& Hopcroft 2006), future climate changes could result in shorter durations of early non-feeding stages. Development time of Thysanoessa spp., derived from the succession observed in the fjord of larval stages from egg to furcilia, was comparable to that of the Antarctic E. superba (Table 3).

\section{Growth rates and mortality of krill development stages}

The overall larval growth rate for the complete development period was $0.05 \mathrm{~d}^{-1}$. The highest growth rate found was during the development of calyptopes $\left(0.12 \mathrm{~d}^{-1}\right)$, corresponding to a daily ration of $37 \%$ body carbon $\mathrm{d}^{-1}$ (Table 4). Smith (1991) found growth rates for $T$. inermis larvae in the Bering Sea during late April to May (0.045 to $\left.0.06 \mathrm{~d}^{-1}\right)$ and June (0.01 to $0.013 \mathrm{~d}^{-1}$ ) and noticed that growth rates of calyptopis stages were higher (maximum of $0.15 \mathrm{~d}^{-1}$ ) than those of nauplii, which also seems to be the case in this study (Table 4). In Pakhomov et al. (2004), daily growth rates of E. superba furcilia were up to $5.7 \%$ of body carbon, being half of those found in the present study (Table 4). Growth rates are generally controlled by food availability (Pinchuk \& Hopcroft 2007), which could explain the difference in growth rates of furcilia in this study from those estimated by Pakhomov et al. (2004), where food concentration was lower. However, both a difference in temperature and the fact that Pakhomov et al. (2004) worked in a different region on a different species could also affect this.

Mortality from eggs to larvae was generally low, with $25 \%$ mortality from egg to nauplius, $48 \%$ from egg to calyptopis and $83 \%$ from egg to furcilia. Mortality of Thysanoessa spp. has typically been greater than that observed here, with estimates of $98 \%$ for the 0+ age group in the Barents Sea (Drobysheva 1987), 93 to $97 \%$ from egg to furcilia in the North Sea in Lindley \& Williams (1980), $97 \%$ in Lindley (1980) and $98 \%$ in Lindley (1978). It is possible that a relatively good larval survival could be a result from living in a fjord (with relatively few predators and competitors) compared to open seas. This is impor- tant information, since the mortality rate affects the recruitment and later population size (Siegel 2000). The estimated mortalities are based on the assumption that the fjord is a closed system; obviously, advective processes contribute to the calculated mortality rates.

\section{Spatial distribution of krill larvae in the Godthåbsfjord system}

In Godthåbsfjord, all developmental stages were found throughout the fjord's length. The cruise represents only a snapshot in time. However, together with the seasonal data, new knowledge of the krill larval community in this region is provided.

During June, calyptopis larvae had developed to maximum numbers in Kapisigdlit, which corresponds to the equally high relative abundance of calyptopes observed throughout the Godthåbsfjord. This is further supported by the cumulative development times calculated from larval abundance estimates in Kapisigdlit, which indicate that krill development had reached the calyptopis stages by the time of the Godthåbsfjord transect. Furthermore, the high egg abundance observed in the central and inner regions of the Godthåbsfjord (Stns GF5 to GF8) can most likely be related to the second spawning event observed in Kapisigdlit. The peak in egg abundance at Stn GF8 may be from spawning by the dominating $T$. raschii (Table 1 in Agersted \& Nielsen 2014). This supports the hypothesis that either T. raschii have prolonged spawning or spawn later than T. inermis (Berkes 1976, Falk-Petersen \& Hopkins 1981, Drobysheva 1987, Plourde et al. 2010). Offshore abundance of older stages (furcilia larvae) was higher than in the fjord. As suggested by Agersted \& Nielsen (2014), eggs and larvae found offshore are most likely T. longicaudata. Even though Agersted \& Nielsen (2014) did not identify larvae to species during their study, they found fertilized females of $T$. longicaudata, which suggests that spawning had occurred. Nevertheless, T. longicaudata have been observed spawning at 9 to $10^{\circ} \mathrm{C}$ (Williams \& Lindley 1982), which is 7 to $8^{\circ} \mathrm{C}$ higher than temperatures in the offshore region during the time of our sampling. As the West Greenland Current impacts the offshore region of Fyllas Bank (Buch 1990), it is perhaps more likely that the northward-flowing current transported T. longicaudata eggs and larvae to the offshore region, as also suggested in Agersted \& Nielsen (2014). From this, it seems likely that the main spawners in the fjord at this time of year are the 
dominating T. raschii, whereas the T. longicaudata seem to be the spawners offshore.

Knowledge and understanding of the reproductive cycle and the factors controlling recruitment are essential in population ecology. However, despite their importance, no previous studies have investigated them for the krill populations in Greenland waters. Here, we document a clear succession from egg to furcilia, with 2 distinct spawning events in the innermost parts of the fjord correlated with the major phytoplankton blooms. Tidal advection and freshwater input determine the distribution of larvae, advecting older stages away from spawning sites like the innermost part of Kapisigdlit. Future changes in timing and magnitude of phytoplankton blooms and meltwater runoff will influence the distribution and growth conditions of krill larvae but also determine the spawning season and recruitment success of the population. Climate-mediated changes in the spatial and seasonal patterns of krill reproduction and larval development will have substantial implications for higher trophic levels in Greenland waters, including the coastal fjords.

Acknowledgements. The research leading to these results received funding from the European Union Seventh Framework Programme project EURO-BASIN (ENV.2010.2.2.1-1) under Grant Agreement No. 264933 and the Greenland Climate Research Centre (project 6505). A special thanks to Professor Charlie Miller for constructive advice and proofreading of the manuscript and to 4 anonymous referees for their constructive comments and suggestions.

\section{LITERATURE CITED}

Agersted MD, Nielsen TG (2014) Krill diversity and population structure along the sub-Arctic Godthåbsfjord, SW Greenland. J Plankton Res 36:800-815

Agersted MD, Nielsen TG, Munk P, Vismann B, Arendt KE (2011) The functional biology and trophic role of krill (Thysanoessa raschii) in a Greenlandic fjord. Mar Biol 158:1387-1402

Arendt KE, Juul-Pedersen T, Mortensen J, Blicher ME, Rysgaard S (2013) A 5-year study of seasonal patterns in mesozooplankton community structure in a sub-Arctic fjord reveals dominance of Microstella norvegica (Crustacea, Copepoda). J Plankton Res 35:105-120

> Astthorsson OS (1990) Ecology of the euphausiids Thysanoessa raschii, T. inermis and Meganyctiphanes norvegica in Ísafjord-deep, northwest-Iceland. Mar Biol 107: $147-157$

Astthorsson OS, Gislason A (1997) Biology of euphausiids in the subarctic waters north of Iceland. Mar Biol 129: 319-330

Berkes F (1976) Ecology of euphausiids in the Gulf of St. Lawrence. J Fish Res Board Can 33:1894-1905

Bi H, Feinberg L, Shaw TC, Peterson W (2011) Estimated development times for stage-structured marine organ- isms are biased if based only on survivors. J Plankton Res 33:751-762

Bjørnberg T (1984) The rejected nauplius, a commentary. In: Schriever G, Schminke HK, Shih CT (eds) Proc Int Conf Copepoda, Ottawa, Canada, Syllogeus Series No. 58. National Museum of Canada, Ottawa, p 232-236

Buch E (1990) A monograph on the physical oceanography of the Greenland waters. Scientific Report No. 00-12, Danish Meteorological Institute, Copenhagen

$>$ Buchholz F, Werner T, Buchholz C (2012) First observation of krill spawning in the high Arctic Kongsfjorden, west Spitsbergen. Polar Biol 35:1273-1279

Calbet A, Riisgaard K, Saiz E, Zamora S, Stedmon C, Nielsen TG (2011) Phytoplankton growth and microzooplankton grazing along a sub-Arctic fjord (Godthåbsfjord, west Greenland). Mar Ecol Prog Ser 442: $11-22$

> Dalpadado P (2006) Distribution and reproduction strategies of krill (Euphausiacea) on the Norwegian shelf. Polar Biol 29:849-859

Dalpadado P, Skjoldal HR (1991) Distribution and life history of krill from the Barents Sea. Polar Res 10: 443-460

Dalpadado P, Skjoldal HR (1996) Abundance, maturity and growth of the krill species Thysanoessa inermis and T. longicaudata in the Barents Sea. Mar Ecol Prog Ser 144:175-183

> Dalpadado P, Ellertsen B, Johannessen S (2008) Interspecific variations in distribution, abundance and reproduction strategies of krill and amphipods in the marginal ice zone of the Barents Sea. Deep-Sea Res II 55: 2257-2265

Drobysheva SS (1987) Population characteristics of abundant Barents Sea Euphausiacea. ICES CM L12:1-15

Einarsson H (1945) Euphausiacea I. Northern Atlantic species. Dana Rep 27:1-184

Falk-Petersen S, Hopkins CCE (1981) Ecological investigations on the zooplankton community of Balsfjorden, northern Norway: population dynamics of the euphausiids Thysanoessa inermis (Kröyer), Thysanoessa raschii (M. Sars) and Meganyctiphanes norvegica (M. Sars) in 1976 and 1977. J Plankton Res 3:177-192

- Flores H, Atkinson A, Kawaguchi S, Krafft BA and others (2012) Impact of climate change on Antarctic krill. Mar Ecol Prog Ser 458:1-19

Gao Q, Xu Z, Huang H, Chen X, Feng C, Li L (2013) Geographical distribution and age composition of Euphausia superba larvae (Crustacea: Euphausiacea) in the South Shetland Islands region and southern Scotia Sea in relation to environmental conditions. Acta Oceanol Sin 32: 59-67

> Gislason A, Astthorsson OS (1995) Seasonal cycle of zooplankton southwest of Iceland. J Plankton Res 17: 1959-1976

Holland DM, Thomas RH, de Young B, Ribergaard MH, Lyberth B (2008) Acceleration of Jacobshavn Isbræ triggered by warm subsurface ocean waters. Nat Geosci 1 : 659-664

Huntley M, Brinton E (1991) Mesoscale variation in growth and early development of Euphausia superba Dana in the western Bransfield Strait region. Deep-Sea Res A 38: 1213-1240

> Ikeda T (1984) Development of the larvae of the Antarctic krill (Euphausia superba Dana) observed in the laboratory. J Exp Mar Biol Ecol 75:107-117 
Jespersen AM, Christoffersen K (1987) Measurements of chlorophyll-a from phytoplankton using ethanol as extraction solvent. Arch Hydrobiol 109:445-454

Jung-Madsen S, Nielsen TG, Grønkjær P, Hansen BW, Møller EF (2013) Early development of Calanus hyperboreus nauplii: response to a changing ocean. Limnol Oceanogr 58:2109-2121

Kiørboe T, Sabatini M (1995) Scaling of fecundity, growth and development in marine planktonic copepods. Mar Ecol Prog Ser 120:285-298

Landry MR (1983) The development of marine calanoid copepods with comments on the isochronal rule. Limnol Oceanogr 28:614-624

Lindley JA (1978) Population dynamics and production of euphausiids. I. Thysanoessa longicaudata in the North Atlantic Ocean. Mar Biol 46:121-130

Lindley JA (1980) Population dynamics and production of euphausiids. II. Thysanoessa inermis and T. raschii in the North Sea and American coastal waters. Mar Biol 59: 225-233

Lindley JA, Williams R (1980) Plankton of the fladen ground during FLEX 76 II. Population dynamics and production of Thysanoessa inermis (Crustacea: Euphausiacea). Mar Biol 57:79-86

MacDonald R (1928) The life history of Thysanoessa raschii. J Mar Biol Assoc UK 15:57-80

Mauchline J, Fisher LR (1969) The biology of euphausiids. Adv Mar Biol 7:1-454

McWhinnie MA, Denys CJ (1978) Biological studies of Antarctic krill, austral summer, 1977-1978. Antarct J US 13:133-135

- Myers PG, Donnelly C, Ribergaard MH (2009) Structure and variability of the West Greenland Current in summer derived from 6 repeat standard sections. Prog Oceanogr 80:93-112

> Mortensen J, Lennert K, Bendtsen J, Rysgaard S (2011) Heat sources for glacial melt in a sub-Arctic fjord (Godthåbsfjord) in contact with the Greenlandic ice sheet. J Geophys Res C 116:C01013, doi:10.1029/2010JC006528

Mortensen J, Bendtsen J, Motyka RJ, Lennert K, Truffer M, Fahnestock M, Rysgaard S (2013) On the seasonal freshwater stratification in the proximity of fast-flowing tidewater outlet glaciers in a sub-Arctic sill fjord. J Geophys Res C 118:1382-1395

Murphy EJ, Thorpe SE, Watkins JL, Hewitt R (2004) Modelling the krill transport pathways in the Scotia Sea: spatial and environmental connections generating the seasonal distribution of krill. Deep-Sea Res II 51:1435-1456

Pakhomov EA, Atkinson A, Meyer B, Oettl B, Bathmann U (2004) Daily rations and growth of larval krill Euphausia superba in the eastern Bellinghausen Sea during austral autumn. Deep-Sea Res II 51:2185-2198

Pedersen T, Fossheim M (2008) Diet of 0-group stages of capelin (Mallotus villosus), herring (Clupea harengus) and cod (Gadus morhua) during spring and summer in the Barents Sea. Mar Biol 153:1037-1046

Editorial responsibility: Edward Durbin,

Narragansett, Rhode Island, USA
Pinchuk AI, Hopcroft RR (2006) Egg production and early development of Thysanoessa inermis and Euphausia pacifica (Crustacea: Euphausiacea) in the northern Gulf of Alaska. J Exp Mar Biol Ecol 332:206-215

> Pinchuk AI, Hopcroft RR (2007) Seasonal variations in the growth rates of euphausiids (Thysanoessa inermis, T. spinifera, and Euphausia pacifica) from the northern Gulf of Alaska. Mar Biol 151:257-269

Plourde S, Winkler G, Joly P, St-Pierre JF, Starr M (2010) Long-term seasonal and interannual variations of krill spawning in the lower St Lawrence estuary, Canada, 1979-2009. J Plankton Res 33:703-714

Pogodin AG (1980) On the development of euphausiid larvae from the northern Tatar Strait in aquaria. Izvestia TINRO 104:70-76 (in Russian)

Riisgaard K, Swalethorp R, Kjellerup S, Juul-Pedersen T, Nielsen TG (2014) Trophic role and top-down control of a subarctic protozooplankton community. Mar Ecol Prog Ser 500:67-82

Rosing-Asvid A, Hedeholm R, Arendt KE, Fort J, Robertson GJ (2013) Winter diet of the little auk (Alle alle) in the Northwest Atlantic. Polar Biol 36:1601-1608

Ross RM, Quetin LB, Kirsch E (1988) Effect of temperature on development times and survival of early larval stages of Euphausia superba Dana. J Exp Mar Biol Ecol 121:55-71

Siegel V (2000) Krill (Euphausiacea) life history and aspect of population dynamics. Can J Fish Aquat Sci 57:130-150

Smith SL (1991) Growth, development and distribution of the euphausiids Thysanoessa raschii (M. Sars) and Thysanoessa inermis (Kroyer) in the southeastern Bering Sea. Polar Res 10:461-478

Swalethorp R, Malanski E, Agersted MD, Nielsen TG, Munk $P$ (2014) Structuring of zooplankton and fish larvae assemblages in a freshwater-influenced Greenlandic fjord: influence from hydrography and prey availability. J Plank Res 37:102-119

Tang KW, Nielsen TG, Munk P, Mortensen J and others (2011) Metazooplankton community structure, feeding rate estimates, and hydrography in a melt-water influenced Greenlandic fjord. Mar Ecol Prog Ser 434:77-90

Teglhus FW, Agersted MD, Arendt KE, Nielsen TG (2015) Gut evacuation rate and grazing impact of the krill Thysanoessa raschii and T. inermis. Mar Biol 162:169-180

Timofeyev SF (1993) Distribution and age composition of euphausiids in waters around the Spitsbergen Archipelago. Oceanology 33:89-92

Turner JT (2004) The importance of small planktonic copepods and their roles in pelagic marine food webs. Zool Stud 43:255-266

Williams R, Lindley JA (1982) Variability in abundance, vertical distribution and ontogenetic migration of Thysanoessa longicaudata (Crustacea: Euphausiacea) in the north-eastern Atlantic Ocean. Mar Biol 69:321-330

Yentsch CS, Menzel DW (1963) A method for the determination of phytoplankton chlorophyll and phaeophytin by fluorescence. Deep-Sea Res Oceanogr Abstr 10:221-231

Submitted: January 23, 2015; Accepted: September 16, 2015 Proofs received from author(s): October 23, 2015 